\title{
Reimaanlok: A National Framework for Conservation Area Planning in the Marshall Islands
}

\author{
Nicole Baker, ${ }^{1}$ Maria Beger, ${ }^{2}$ Caleb McClennen, ${ }^{3}$ Albon Ishoda, ${ }^{4}$ and Florence Edwards ${ }^{5}$ \\ ${ }^{1}$ Kelburn, Wellington 6012, New Zealand \\ ${ }^{2}$ The Ecology Centre, The School of Biological Sciences, The University of Queensland and The Commonwealth Research Facility for \\ Applied Environmental Decision Analysis, Brisbane, QLD 4072, Australia \\ ${ }^{3}$ Global Marine Program, Wildlife Conservation Society, 2300 Southern Boulevard, Bronx, NY 10460, USA \\ ${ }^{4}$ Marshall Islands Conservation Society, Majuro, MH 96969, Marshall Islands \\ ${ }^{5}$ Marshall Islands Marine Resource Authority, Majuro, MH 96969, Marshall Islands
}

Correspondence should be addressed to Nicole Baker, nicole.f.baker@gmail.com

Received 16 June 2010; Accepted 26 October 2010

Academic Editor: Judith D. Lemus

Copyright (C) 2011 Nicole Baker et al. This is an open access article distributed under the Creative Commons Attribution License, which permits unrestricted use, distribution, and reproduction in any medium, provided the original work is properly cited.

\begin{abstract}
The development of Reimaanlok, a national framework for the planning and establishment of community-based conservation areas in the Marshall Islands, is outlined. A team composed of international experts and local resource management professionals selected and modified an ecoregional planning approach, defined key concepts, selected conservation features and targets, compiled biogeographical information from scientific and local knowledge and carried out a national-level ecological gap assessment. Past development of community-based fisheries and conservation plans was reviewed and the lessons learned informed the development of a robust community-based planning process for the design and establishment of conservation areas on individual atolls, integrating ecosystem based management (EBM) theory, traditional knowledge and management, and the particular socio-economic needs of island communities. While specific geographic, historical, cultural and economic characteristics of the Marshall Islands have created a framework that is unique, several aspects of this process offer ideas for national strategic conservation planning in other Small Island Developing States where there is a paucity of scientific data, significant and increasing threats, and where decision-making about the use of natural resources occurs primarily at the local level.
\end{abstract}

\section{Introduction and Background}

Coral reefs are degrading globally at an increasing rate $[1,2]$; this is expected to worsen, as localized impacts including overfishing and land-based pollution are compounded by the array of impacts from climate change and ocean acidification $[3,4]$. Few pristine reefs exist even now $[5,6]$, underpinning the conservation priority of such refuge reefs to enhance reef persistence in the future. Global efforts to mitigate the drivers of global climate change are crucial [7], but limiting localized impacts on reef ecosystems through improved resource management and conservation is essential for long-term adaptation [8-10]. Systematic conservation planning using spatial prioritization is becoming a widely used approach $[11,12]$ to identify representative networks of protected areas that will be resilient in the face of these increasing threats
[13]. At the same time, in the Pacific Islands, centuries-old customary marine management was in decline but is now experiencing a "renaissance" in the form of communitybased management [14].

In the face of global losses of biodiversity, the Marshall Islands retain some of the healthiest and most pristine coral reef systems anywhere in the world $[15,16]$. In recent years, however, biodiversity in the Marshall Islands has become threatened by increased pressures on fisheries, climate change, and sea-level rise, increased urbanization and pollution, and a loss of the traditional subsistence lifestyle central to the identity and well-being of the Marshallese people $[17,18]$. These trends have strengthened commitment within the Marshall Islands to establish and manage community-based conservation areas in addition to other resource conservation strategies. In 2006, the President 
of the Marshall Islands signed the Micronesia Challenge, a commitment by Micronesian countries and territories to "Effectively Conserve 30\% of Nearshore Marine and 20\% of Terrestrial Resources by 2020" [19].

To this end, in the Marshall Islands the development of a national framework for the planning and establishment of community-based conservation areas sought to reconcile international imperatives for conservation with the need for a locally-driven approach underpinned by a sense of ownership and the intimate environmental knowledge of local people [20]. This project and the resulting document were called "Reimaanlok"-Marshallese for "looking to the future, together." Reimaanlok incorporated a national-scale ecological gap assessment along with the development of a locally appropriate process for the empowerment of Marshall Island communities to establish and manage conservation areas. Here, we discuss the process of integrating traditional knowledge, local needs, modern conservation planning methods, and learning about these components in a locally led project.

\section{The People, Biodiversity, and Management Needs of the Marshall Islands}

Twenty-nine low-lying coral atolls and five low coral islands rise over 6,000 meters from the seabed to the surface of the equatorial Pacific and comprise the islands known to the Marshallese as Aelōn Kein (Sea Sky Land) (Figure 1). The Exclusive Economic Zone (EEZ) of the Marshall Islands is over 2 million $\mathrm{km}^{2}$, and less than $0.01 \%\left(183 \mathrm{~km}^{2}\right)$ is land. A total of 1,225 individual islands and islets make up the Ratak (Sunrise) chain in the east and the Ralik (Sunset) chain in the west. The atolls consist of biotic limestone on a deep basalt core, built over millions of years by coral reefs that grew as the basalt core slowly subsided [21,22], creating a coral reef system extremely rich in productivity, diversity, and complexity. The modern islands only formed between 2,000 and 4,000 years ago, amid a slight lowering of sea level [21]. The region was settled by the direct ancestors of today's Marshallese around 500 BC [23]. Today, around 60,000 people live in the Marshall Islands, with two-thirds of these in the urban centers of Majuro and Ebeye, and the remaining living in low population density on twenty atolls and four islands [24].

Marshallese are excellent seafarers, canoe builders, and fishermen whose life has always been closely related to the ocean and its many creatures [25]. In the past, traditional fishing methods ranged from the simple line and hook to nets, traps, spears, clubs, rope, and coconut fronds and were accompanied by complex taboos, social hierarchies, procedures, and magic chants that integrated the spiritual, social, and economic lives. Methods were specialized for specific fisheries, fishing grounds, and seasons [25]. While some traditional fishing methods remain in use today, many are being lost along with the social and cultural complexities that essentially led to sustainable use of marine resources. Rising population levels, capital investment in the fishery sector, and increased international trade in fishery products have resulted in an erosion of the prevalence of traditional methods and associated sociocultural organization and are resulting in unprecedented levels of fishing pressure on both the nearshore and pelagic fisheries $[17,18]$. However, fish and other marine resources remain important subsistence and commercial foods, the catching and sharing of which revive culture and community $[25,26]$.

Though scientific study of the islands has been limited due to their remoteness, those studies that have been carried out reveal a rich catalogue of biodiversity, including over 1000 species of fishes [27], over 362 species of corals [16, 28], 40 sponges, 1655 molluscs, 728 crustaceans, 128 echinoderms, 27 marine mammals, and 5 turtle species [29].

From 1946 to 1958, the US military carried out 67 tests of nuclear weapons on Bikini and Enewetak [30,31]. While the atolls of Bikini, Enewetak, Rongelap, Ailinginae, and Utrik received the bulk of radioactive fallout from these tests, most atolls in the Marshall Islands received some radiation [32]. Impacts on biodiversity have been significant; while hard coral communities in Bikini Atoll have largely recovered after five decades, local extinctions of lagoonal specialist species [16], high concentrations of cesium-137 in terrestrial biota [33], and massive craters more than a mile across provide a lasting legacy of this history. Conversely, the nuclear legacy has yielded a de facto form of biodiversity protection as previously highly habitable islands are now unpopulated and access has been severely restricted or prohibited.

While the Marshall Islands Government has the authority at a national level to manage, sustainably develop, and conserve its natural resources, decision making about the use of the resources occurs almost entirely within local communities. Local governments have jurisdiction over the resources within five nautical miles of its shores, but decisions are often made under the guidance of traditional leaders. Traditional conservation practices, governed by iroij (chiefs), were designed to protect and manage natural resources in order to secure reliable food supplies. One of the methods remaining in use in limited areas is " $m o$ "the traditional system to designate parts of land, a whole island, or a reef area, as a restricted site. Special permission from the iroij was required to visit a mo, and harvesting would be done only for special occasions or in times of critical need, such as a drought. The rules and regulations for $m o$ varied across the archipelago and would often involve rituals and chants, and violations were believed to result in consequences mystical in nature [25]. Other measures were in place to manage the sustainable harvest of populations including seasonal harvesting restrictions, size limits, and prohibition of extraction of gravid females [29]. While some evidence of these traditional management measures remain, even stronger is the evidence of their erosion and the lack of modern management measures effectively taking their place [17].

To fill this gap, various efforts have been made to establish community-based conservation areas throughout the Marshall Islands. Some have been led by the Marshall Islands Marine Resources Authority (MIMRA) with the support of regional fisheries agencies as part of the development of sustainable local fisheries (for example, Arno and Likiep); 
TABLE 1: Definitions of Reimaanlok concepts and terms as developed in workshops.

\begin{tabular}{|c|c|}
\hline Term & Definition \\
\hline $\begin{array}{l}\text { Nearshore Marine } \\
\text { Resources (NMR) }\end{array}$ & $\begin{array}{l}\text { Resources below the high water mark oceanward to a depth of approximately } 100 \mathrm{~m} \text {, and including the entire } \\
\text { lagoon. Given this definition, there are } 14,067 \mathrm{~km}^{2} \text { of NMR in the RMI. }\end{array}$ \\
\hline $\begin{array}{l}\text { Effective } \\
\text { Conservation }\end{array}$ & $\begin{array}{l}\text { Management that (a) maintains or improves atoll ecosystems, their biodiversity, health, productivity, and } \\
\text { integrity, (b) sustains artisanal subsistence use of resources, and (c) protects and preserves areas of significant } \\
\text { natural and cultural heritage. Areas under Effective Conservation have (a) publicly developed, legitimately } \\
\text { recognized, and actionable management plans with clear objectives, (b) long-term biological and } \\
\text { socio-economic monitoring and evaluation against management objectives, and (c) some form of recognized } \\
\text { customary or legal rules and compliance system. Areas under Effective Conservation are part of a national } \\
\text { system of conservation areas that includes representation of all habitat types and special conservation targets. }\end{array}$ \\
\hline $\begin{array}{l}\text { Types of } \\
\text { Conservation Areas in } \\
\text { the Marshall } \\
\text { Islands-Type } \\
\text { I-Subsistence Only }\end{array}$ & $\begin{array}{l}\text { This area is managed for subsistence noncommercial use. In international standards, this relates to IUCN } \\
\text { Category VI-Managed Resource Protected Area. The management area may include some Type II-Special } \\
\text { Reserve no-take or highly restricted areas as part of the management regime. }\end{array}$ \\
\hline $\begin{array}{l}\text { Types of } \\
\text { Conservation Areas in } \\
\text { the Marshall } \\
\text { Islands-Type } \\
\text { II-Special Reserve }\end{array}$ & $\begin{array}{l}\text { This area is subject to a high level of protection, and occasionally a very low level of subsistence or special } \\
\text { occasion activities. In international standards, this relates to IUCN Category Ib-Wilderness Area. Examples of } \\
\text { this are the atolls of Ailinginae and Bikini that have high levels of protection and restrictions on human } \\
\text { activities }\end{array}$ \\
\hline
\end{tabular}

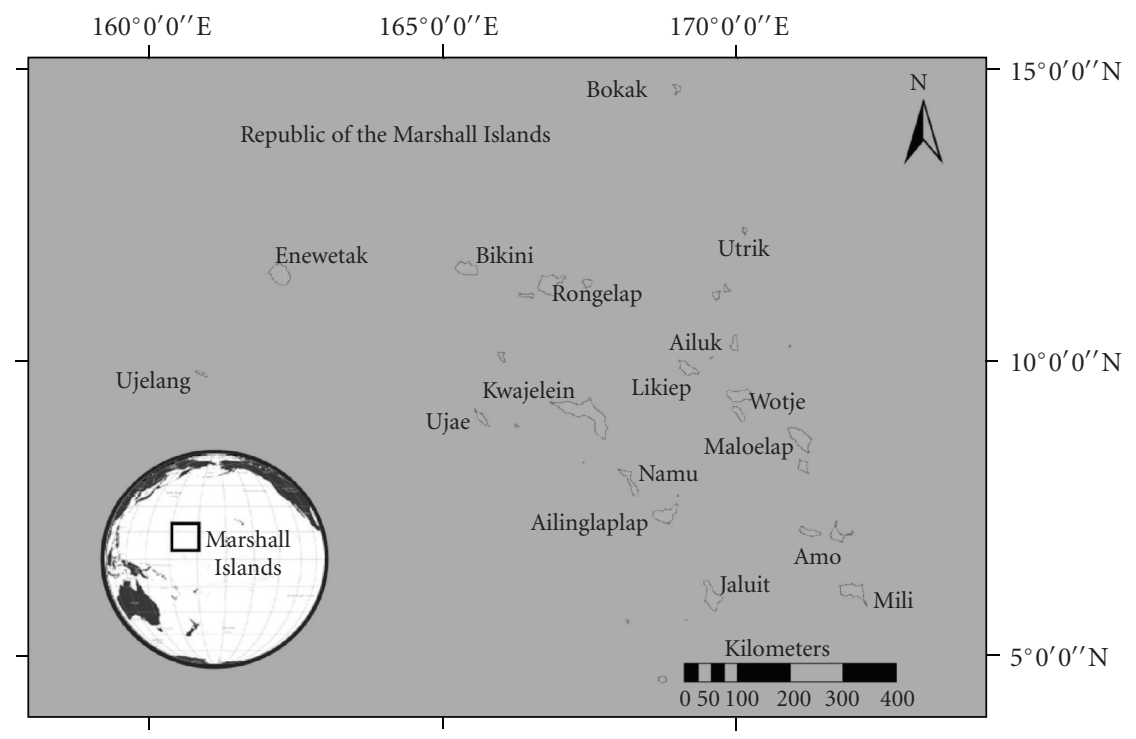

Figure 1: Map of the Marshalls Islands.

some have been led by the national Environment Protection Authority (RMIEPA) with a focus on balancing biodiversity conservation with sustainable livelihoods (for example, Jaluit Atoll Conservation Area). In addition, some communities and leaders have pursued the establishment of conservation areas independently, through issuing local government ordinances and working with international researchers (for example, Ailinginae, Ailuk, and Bikini).

As this range of conservation initiatives developed, with varying degrees of success, the need for an overarching framework for conservation area planning became apparent in order to provide clear direction for national agencies on how they could best assist local communities and to provide a focus for funding and assistance from international donors. The development of the Reimaanlok framework and of accompanying processes and guidelines was driven by this need.

\section{Towards a National Framework for Conservation and Sustainable Resource Management}

The development of an overarching national framework of conservation planning and resource management was led by a core team of international specialists and local resource 
TABLE 2: Conservation features and targets in the Marshall Islands.

(a) Coarse-scale conservation features and targets: Broad categorization of habitats and ecosystems that encompass all the biota of the Marshall Islands.

\begin{tabular}{|c|c|c|}
\hline Feature & $\begin{array}{c}\text { Type I target } \\
\text { subsistence only }\end{array}$ & $\begin{array}{l}\text { Type II target } \\
\text { special reserve }\end{array}$ \\
\hline \multicolumn{3}{|l|}{ Terrestrial } \\
\hline Agroforests & $50 \%$ & \\
\hline Indigenous broadleaf forests & $20 \%$ & $10 \%$ \\
\hline Wetlands & $80 \%$ & \\
\hline \multicolumn{3}{|l|}{ Marine } \\
\hline Deep lagoon & $30 \%$ & $0-5 \%$ \\
\hline Lagoon pinnacles & $30-40 \%$ & $0-15 \%$ \\
\hline Lagoon slope & $50 \%$ & $0-15 \%$ \\
\hline Ocean leeward reef liklal & $30-50 \%$ & $0-10 \%$ \\
\hline Ocean Reef & $100 \%$ & \\
\hline Ocean windward reef & $30-50 \%$ & $0-10 \%$ \\
\hline Reef flat & $30-50 \%$ & $0-10 \%$ \\
\hline Reef pass and channel & $80-100 \%$ & $0-30 \%$ \\
\hline
\end{tabular}

(b) Fine-scale conservation features/special features. Important areas for species, rare or imperiled communities, places of cultural significance. These are features considered worthy of conservation consideration that are not adequately dealt with under the coarse-scale features above.

\begin{tabular}{|c|c|c|}
\hline Feature & $\begin{array}{c}\text { Type I target } \\
\text { subsistence only }\end{array}$ & $\begin{array}{l}\text { Type II target } \\
\text { special reserve }\end{array}$ \\
\hline \multicolumn{3}{|l|}{ Terrestrial } \\
\hline Bird Island & $100 \%$ & $50 \%$ \\
\hline Breadfruit forest $m \bar{a}$ & $100 \%$ & $0 \%$ \\
\hline $\begin{array}{l}\text { Climax forest communities: Pisonia grandis kañal and } \\
\text { Neisosperma oppositifolium kōjbar forests }\end{array}$ & $20 \%$ & $10 \%$ \\
\hline Mangrove area jon, bulabol and kimeme & $90 \%$ & ? \\
\hline Pemphis acidula forest kōne & $100 \%$ & $50 \%$ \\
\hline Pond pat & $60-80 \%$ & ? \\
\hline Shrubland and grassland & $100 \%$ & $50 \%$ \\
\hline Turtle nesting beach & $100 \%$ & $100 \%$ \\
\hline Windward forest $j \bar{a} \bar{n} a r$ & $100 \%$ & \\
\hline \multicolumn{3}{|l|}{ Marine } \\
\hline Clam site & $50 \%$ & $30 \%$ \\
\hline Fish spawning aggregation area (SPAG) & $100 \%$ & NA \\
\hline Point with extended ocean reef $b \bar{o} k e$ & $?$ & \\
\hline Reef hole nam & $30 \%$ & \\
\hline Seagrass meadow & $100 \%$ & \\
\hline
\end{tabular}

? indicates that these targets remained undetermined.

(c) Species conservation features.

\begin{tabular}{l}
\hline Terrestrial \\
\hline Aquatic shrimp \\
Arno skink \\
Horticultural species bōb (Pandanus tectorius clones), iaraj (taro) \\
Land crabs atuñ, baru wan, barulep \\
\hline
\end{tabular}


(c) Continued.

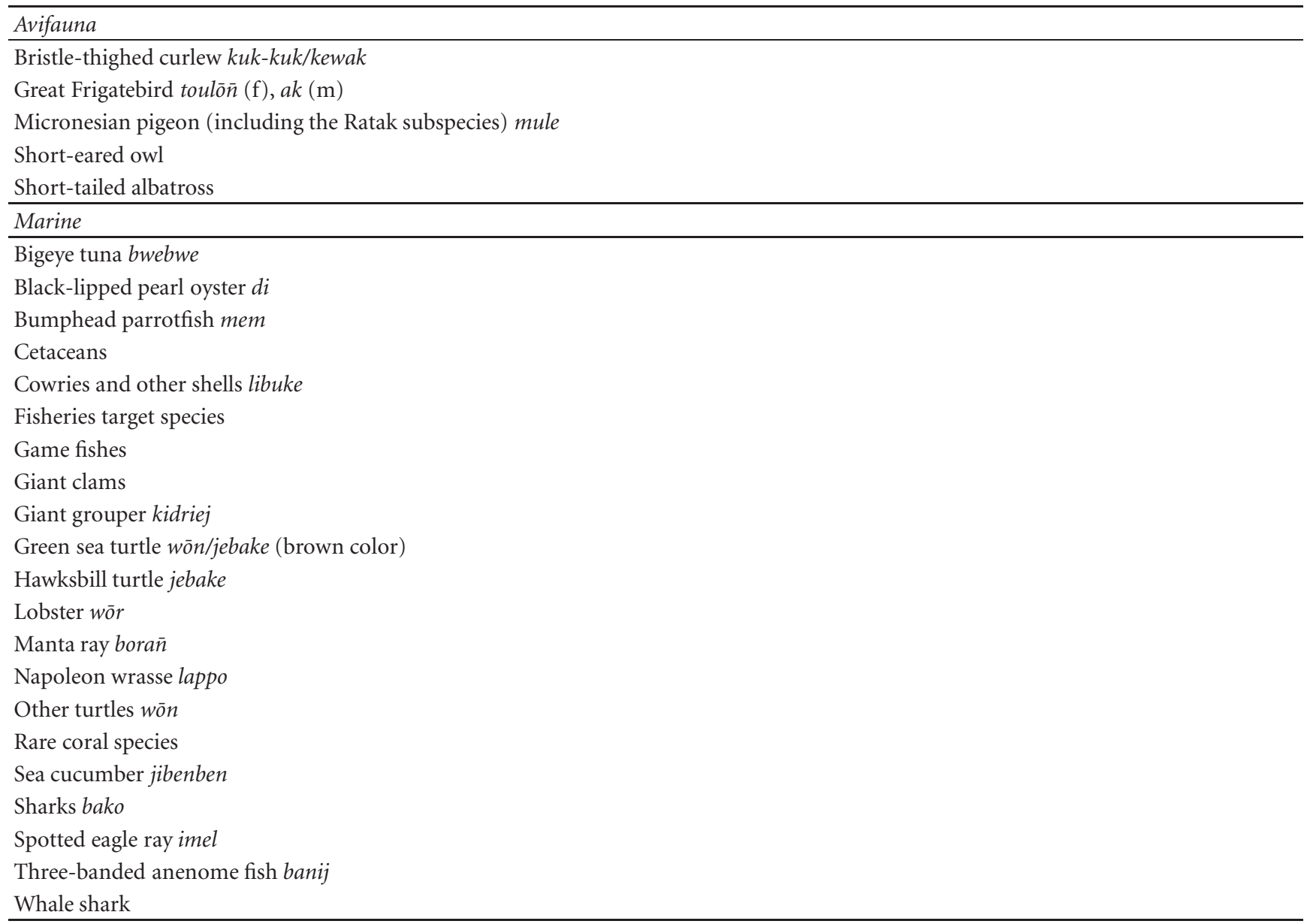

Notes on Tables 2(a), 2(b), and 2(c). The values in Table 2(a) for coarse-scale conservation features are area based; thus, the \% refers to a portion of the total area of that habitat type. The values in Table 2(b) for fine-scale conservation features are based on occurrences. That is the $\%$ refers to a portion of the total number of occurrences of the target. For example, if 200 climax forest communities in the Marshalls are identified, then 20 (10\%) should be protected and another 20 managed for subsistence use only. A total of 40 areas (20\%) should be under effective conservation. Often the fine-scale features are too small to easily map (consider a turtle nesting beach), and so the targets are set by occurrences rather than by area. Conservation targets are location and area based; therefore, there are no targets set for species conservation features (Table 2(c)). Some conservation features do not have targets associated with them due to uncertainty within the planning team about appropriate targets. It is expected that the importance of these conservation features and appropriate goals will be determined during atoll-level conservation planning processes.

management professionals, including all the authors of this paper. A far larger group of people from all government and nongovernment resource management agencies operating at a national level was involved in the development of the framework through workshops, interviews, and reviewing documents. This planning process was used as an opportunity for local institutions to create and manage a program through a process of group learning and consensus building [34]. The intent of this was to build "locally adaptive institutions" [35] for effective conservation in the Marshall Islands.

\subsection{Conceiving of a "Hybrid" Approach to Conservation} Management. For conservation efforts to be successful and sustainable, conservation programs should be carried out within the constraints set by the local culture [36]. Some features of community-based management are universal and fundamental to its success: ownership of the resources and the intimate knowledge of the environment held within a community [37, 38]. Meanwhile, conservation planners have developed spatially explicit, systematic approaches to design an ecologically representative and functional network of conserved areas (usually referred to as ecoregional planning or systematic conservation planning) [11-13].

Often, in ecoregional planning processes, the approach taken is to identify a portfolio of sites to be considered and, from these, to select actual sites as priorities for conservation $[11,13,39,40]$ based on a systematic evaluation of the locations of conservation targets, the gap assessment and other factors (see, e.g., Green et al. [41] and The Nature Conservancy [42]). The challenge for the Reimaanlok team was to combine the modern western concepts of systematic conservation planning with indigenous knowledge and 


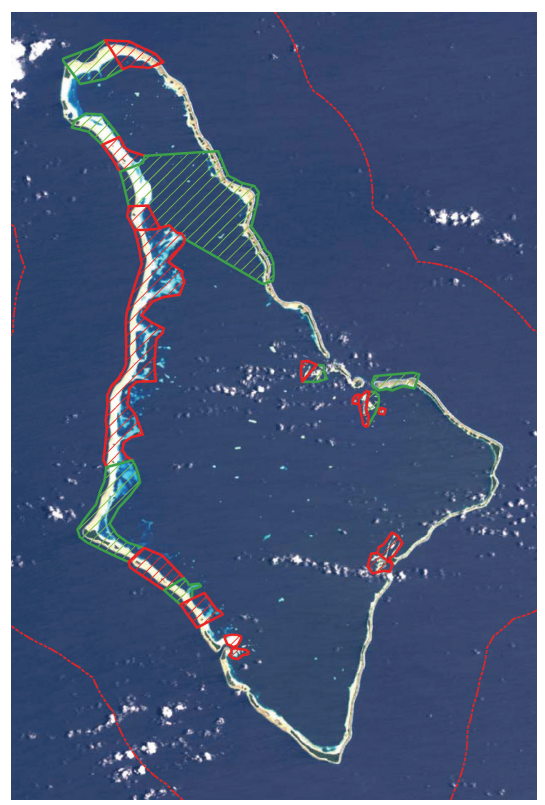

Figure 2: Example of mapping of existing conservation areas on Jaluit Atoll. Type I areas (managed subsistence use only) are mapped in green and Type II areas (high level of protection) are mapped in red.

management actions to form "hybrid" [20] or "multicultural plans" [36].

The team spent much time debating an approach that would work for the Marshall Islands and developing the process and the conceptual framework for building the plan. This resulted in a commitment to carry out several steps in the ecoregional planning process including identifying conservation features, setting conservation targets, collating biogeographic information, and carrying out a gap assessment. Importantly, in this national-level planning process, it was decided to stop short of identifying a portfolio of possible sites and prioritizing these sites for conservation action because "the biodiversity of each atoll is important to those people who live on it, all atolls have areas worth conserving, and only the community and landowners of that atoll have the right to determine which sites they will conserve" [43]. Instead, a detailed process for conservation planning at the level of each atoll was developed to ensure that the process would be led by local stakeholders and resource owners. This approach still enables the objective of a representative network of conservation areas to be met, because each of the Marshallese atolls have a similar array of habitats and geomorphology, in contrast to other countries, where heterogeneous terrain and habitat means establishment of a representative network often involves selecting very specific sites.

3.2. Selecting an Ecoregional Planning Framework and Defining Concepts. Initially, the core team considered various models for an ecoregional planning framework (see Redford et al. [11] for a review of various approaches) before settling on The Nature Conservancy's "Designing a Geography of
Hope" [39]. Primarily, this was chosen to ensure that the terminology and concepts aligned with those used in other Micronesian countries (especially Palau and the Federated States of Micronesia), where TNC has been active in conservation planning [42]. To ensure stakeholder input and participation, a series of workshops was held to discuss and develop (a) objectives for conservation in the Marshall Islands; (b) conservation features: those elements of biodiversity to be conserved; (c) conservation targets: how much of each conservation feature is to be conserved; and (d) definitions for key concepts including "Effective Conservation" and "Nearshore Marine Resources" from the Micronesia Challenge commitment (Table 1).

From the start, Marshallese staff worked closely with international conservation planners to determine the process and define these underpinning concepts in what became an ongoing dialogue of two distinct forms of cultural knowledge about how to do conservation [20,36]. This meant grappling with such fundamental concepts as "protected areas," a favored term in the global conservation vernacular but an unfamiliar concept in the Pacific islands, where traditional management schemes are more sophisticated than a simple "keep out" $[14,20]$. As a result, this discourse has empowered the Marshallese team members to engage in the debate about conservation methods on an equal level with international "experts."

3.3. Selecting Conservation Features. Conservation features were defined as the elements of biodiversity and related cultural features that will be the focus of conservation and management planning efforts. Very simply, they are the things that are to be conserved or managed. A "coarsefilter/fine-filter" approach to consider conservation features at different spatial scales was adopted for this [40]. Conservation features were grouped into three types:

(a) coarse-scale conservation features/environmental units broad categorization of habitats and ecosystems that encompass all the biota of the Marshall Islands;

(b) fine-scale conservation features/special features Important areas for species targets, rare or imperiled communities, and places of cultural significance;

(c) species conservation features threatened species, endemic/restricted range, flagship species, species of cultural significance, and species of economic importance.

Conservation features for the Marshall Islands were identified in three workshops of the national planning team, a literature review and extensive consultation with national and international experts familiar with the biodiversity, and ecosystems of the Marshall Islands. The list was subsequently refined over a period of six months in discussions (Table 2).

\subsection{Collating Scientific and Local Knowledge about People and} Biodiversity. A spatial database of conservation features, patterns and intensity of use, cultural aspects, and existing management areas is a prerequisite for systematic conservation 
planning. Information about biodiversity in the Marshall Islands was compiled into a Geographic Information System (GIS). The spatial elements of the GIS were digitized from multiple data sources, including high resolution satellite imagery (including ASTER, Landsat, and QuickBird), nautical charts, and coral reef habitat maps developed by the Institute for Marine and Remote Sensing (IMARS) [44]. These maps provided a vector-based delineation of coarsescale marine conservation features on a national scale.

Information about special biodiversity and cultural features was collated from review of literature and from interviews with local knowledge experts and scientists. Local and traditional knowledge on occurrences of conservation features was gathered by interview with more than 15 people knowledgeable about resources and special features in different atolls. Simple maps and data recording sheets were used to collect the information, which was then entered into the GIS. This process yielded the recording of over 500 special biodiversity or traditional management locations across the entire Marshall Islands.

While there is, in general, a paucity of scientific data on biodiversity in the Marshall Islands, the project was successful in creating processes to collect, document, and use local and traditional environmental knowledge. At the national level, this data augments the scarce scientific data to better inform the systematic planning process. The real value, however, is that the process of collecting and discussing, and thereby valuing and validating, local and traditional environmental knowledge is crucial to reducing inequities in knowledge and power between scientists and local people $[34,36]$ and is a prerequisite for ensuring participation and ownership [34, 37] and, therefore, success of conservation efforts. This cultural empowerment creates opportunity for long-term collaboration and dynamic development of information [36] between outsiders and locals, brings creativity to the challenge of conservation [34], and contributes to building adaptive institutions.

3.5. Setting Conservation Targets. Once occurrences of conservation features had been mapped, a consensus-based process was used to establish long-term national conservation targets for these features (Tables 2(a) and 2(b)), intended to meet or exceed the Marshall Islands' commitment to the Micronesia Challenge. The Micronesia Challenge targets are inline with internationally accepted good practice: for example, $30 \%$ protection of marine resources was achieved in the Great Barrier Reef Marine Park [45] and the Channel Islands [46] and has been highlighted as the minimum amount necessary to allow reefs to persist in the long term [47]. Guided by these commitments, and to improve resolution of the national conservation targets, a further guideline was explicitly stated to aim for $30 \%$ of Nearshore Marine and $20 \%$ of terrestrial areas under effective conservation on each individual atoll. It was recognized, however, that, while for some unpopulated atolls the achievement of this goal may be easy, for others, such as the heavily developed atoll of Majuro, it will be much more difficult. The setting of targets and their division into levels of protection as Type I areas (subsistence use only) and Type II (special reserve) reflects the thoughts of the planning participants on the degree of protection required by different features, taking into account the rarity and condition of occurrences of features, and their vulnerability to harvesting pressures.

This process was subject to all the uncertainties that often hamper conservation planning including a limited understanding of the area that needs to be protected to maintain habitats and species and to ensure the persistence of ecological processes [12, 40,48]. While it was an important process to determine conservation targets, the discussions in the workshops highlighted the need to keep in mind the objective of maintaining the community support for resource management as more important to long-term effectiveness than achieving the exact targets [49].

3.6. Ecological Gap Assessment. Existing and planned conservation areas were mapped (see Figure 2 for the example of Jaluit Atoll) and categorised as Type I (managed subsistence use only) or Type II (high level of protection). A gap assessment was carried out using GIS analysis to determine how successful these existing conservation areas are in meeting the conservation targets. This gap assessment showed that existing or proposed conservation areas covered $18 \%$ of total Nearshore Marine Resources in the Marshall Islands (Table 3). Coverage was varied as many atolls have no conservation areas, while others, such as Bikini or Ailinginae, are $100 \%$ protected. Importantly, this assessment did not cover the effectiveness of the current management or degree of implementation, as monitoring and evaluation systems are not properly in place.

3.7. Key Principles for Establishing Community-Based Conservation and Management. The national framework recommends replicating community-based management in several atolls, moving away from identifying priority areas nationally to use existing administrative arrangements that support community-based management. Local buy-in and efficiency of resource management is best where the communities' needs drive the process $[14,20,38]$, yet many Marshallese atoll communities lack the resources and capacity to establish management plans without assistance from national agencies. Previous experiences of developing communitybased fisheries management plans and other conservation plans were discussed within a group of local resource management professionals. The challenges of these projects were discussed, and translated into several key principles for establishing community-based conservation and management in the Marshall Islands.

(1) Focus on Community Leadership and Social Sanctions. In the past, the focus has been on western-style mechanisms for compliance, such as local or national government regulations, legal enforcement, and the use of the judicial system for sanctions. Discussion revealed that local regulations had often not been officially signed off by the local governments and, even where they had, there was substantial noncompliance. It was determined that the most effective 
Proposed community-based resource management/

conversation planning process

(1)

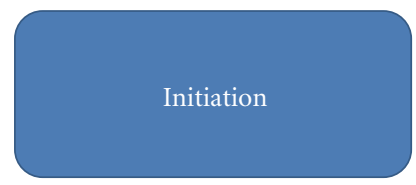

(2)

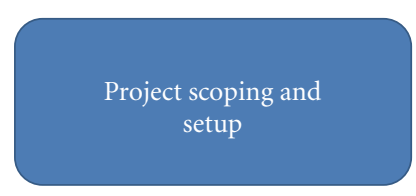

(3)

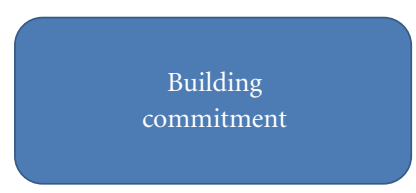

(4)

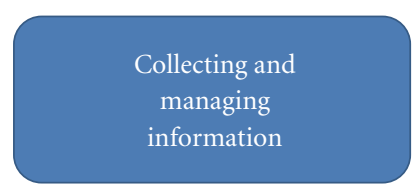

(5)

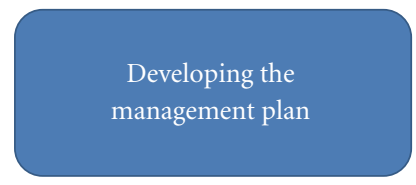

(6)

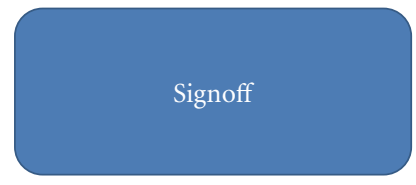

(7)

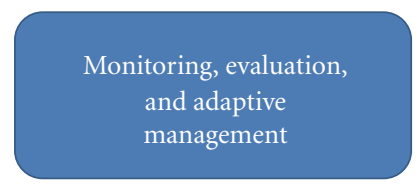

(8)

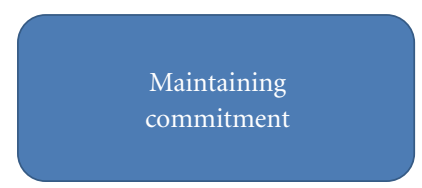

A need to develop a community-based resource

management plan is identified either at local government level or at national level

Establishment of a project workplan, a team of facilitators, and identification of budget and resources

An initial visit is made by the national team to carry out education and awareness about the benefits of conservation and resource management and to build trust with the community

Further visits focus on collection and
documentation of
mapping local knowledge and use of resources,
socioeconomic information, and
baseline scientific information

Several visits are made to the community to develop, draft, and revise a detailed management plan

Achieve commitment to the plan through signoff of management plan

Monitor achievements of biological and socioeconomic objectives and adapt the management plan accordingly

Ensure community has adequate support for ongoing management

FIGURE 3: Summary diagram of the process for community-based conservation and resource management planning.

compliance could be achieved within a community through direction from traditional leaders and other respected leaders, accompanied by associated social sanctions. Regulations and legal authority were considered a secondary priority.

(2) Projects Are Initiated by the Community. Often, in the past, the projects had been initiated by people outside the community and when discussed in light of the perceived successes and failures, this was thought to be an inefficient use of valuable institutional resources as it had a low chance of being fully successful. It was decided that support would be prioritized for those atolls and communities that actively request assistance for the development of conservation plans.

(3) Ensure Adequate Time and Commitment of Resources by Marshallese Agencies. Review of past success and failure revealed that insufficient time and resources had been committed to individual communities to ensure consensus and buy in to the management planning process. Previously, plans had often been written by international "experts" with only one or two visits to an atoll community by national staff. It was decided that the development of each plan should involve considerable long-term community engagement with numerous consultations, facilitated by Marshallese staff from national agencies 
TABLE 3: Gap assessment: current area under conservation against the goals for coarse-scale conservation features.

\begin{tabular}{|c|c|c|c|c|}
\hline Feature & Total area $\left(\mathrm{km}^{2}\right)$ & Area under conservation $\left(\mathrm{km}^{2}\right)$ & Percentage under conservation & Target \\
\hline Ocean reef & 627.33 & 108.35 & $17 \%$ & $50 \%$ \\
\hline Lagoon slope & 1120.48 & 258.82 & $23 \%$ & $50 \%$ \\
\hline Reef pass and channel & 646.70 & 133.89 & $21 \%$ & $80 \%$ \\
\hline Lagoon pinnacles & 77.82 & 9.64 & $12 \%$ & $40 \%$ \\
\hline Reef flat & 1354.58 & 316.88 & $23 \%$ & $50 \%$ \\
\hline Total nearshore marine & 3826.91 & 827.58 & $22 \%$ & $30 \% *$ \\
\hline Deep lagoon & 10239.65 & 1727.16 & $17 \%$ & $30 \%$ \\
\hline Total marine & 14066.56 & 2554.74 & $18 \%$ & - \\
\hline Land & 184.65 & 28.94 & $16 \%$ & $20 \% *$ \\
\hline Total & 14251.21 & 2583.68 & $18 \%$ & \\
\hline
\end{tabular}

Area under conservation refers to an estimate of the amount currently described in management plans or local government ordinances as being under Types I or II of management and also those areas proposed in the near future to be under management.

* Micronesia Challenge Commitment

(Figure 3). This extended time commitment would allow for the development of trust between national staff and communities, time for bwebwenato (talking stories), sharing knowledge, discussion of a variety of resource management options, and, most critically, time to reach genuine consensus on the processes for managing the resources by the community. It was further determined that there was need for greater commitment to ongoing support for atoll communities in monitoring and evaluation and in enabling adaptive management far beyond the initial multiyear management planning exercise.

(4) Use Appropriate Tools for Community-Based Planning. It was discussed that one of the limitations of past work had been a lack of adequate tools available to support problem analysis and decision making within the community. The tool most often used in the past was the "problem-solution tree" (see, for example, King and Faasili [50]) which had been useful for its simplicity but was no longer sufficient to frame the discussion of conservation and resource management within the communities. The team decided that a wider range of tools was required and that these tools should be customized to the particular cultural context of the Marshall Islands. The Locally Managed Marine Areas Guide for Practitioners [51] was adopted as the basic toolkit, having been developed for this purpose for Pacific Islands. The team developed other tools specifically for the Marshall Islands context including atoll-level conservation area design principles that incorporate ecological and socio-economic considerations and a culturally specific process for the collection and documentation of local and traditional knowledge using community-based mapping [43].

(5) Integrate Multiple Realms and Objectives: Marine, Terrestrial, Human. To improve upon approaches building on only a single conservation objective, it was decided that resource management and conservation plans should be holistic and consider coastal management issues along with terrestrial and marine biodiversity conservation, in the context of local food security and economic needs. Apart from the obvious utility of integrated conservation planning, this approach also reduces consultation fatigue in communities and duplication of efforts by national and international agencies. This latter issue is particularly important in a relatively small country like the Marshall Islands with a limited pool of human resources.

Based on these principles a working group developed the 8-step Process for Community-Based Fisheries and Resource Management Planning, as a set of guidelines for facilitators to assist communities in the development of community-based resource management and conservation plans (Figure 3).

\section{Conclusions}

The development of Reimaanlok responded to international imperatives for the establishment of a national protected area network (in particular the Convention on Biological Diversity Program of Work on Protected Areas and the Micronesia Challenge) while ensuring that the detail of the conservation objectives and targets, the policy settings, and the program design were applied to the context of the Marshall Islands, with its particular mix of western style government and traditional governance and cultural structures. As a result, Reimaanlok did not attempt to identify specific sites for conservation areas but rather carried out a nationalscale ecological gap assessment and developed the principles, process, and guidelines for the design, establishment, and management of conservation areas that are fully owned, led, and endorsed by local communities based on their needs, values, and cultural heritage. In informing the development of the plan, a combination of scientific rationalist knowledge, provided largely by visiting international scientists, and local and traditional knowledge of ecosystems, biodiversity, and sociocultural information was used. All this information is equally valid and was treated as such. The intention of 
the Reimaanlok process was to serve as a frameworkbuilding process to allow for implementation of on-ground conservation outcomes.

While there are geographic, historical, cultural, and economic characteristics of the Marshall Islands that require this framework to be specific to these particular circumstances, several aspects of this process offer ideas for national strategic conservation planning of Small Island Developing States more generally. In particular, it is important to engage with global agendas for biodiversity, but equally important to find the most appropriate way within each country's own system to achieve those objectives, while making use of international assistance, where it is useful.

\section{A Note about Terminology}

In Reimaanlok: National Conservation Area Plan for the Marshall Islands, we adopted the terminology from The Nature Conservancy's model for ecoregional planning. To minimise confusion, we have adopted terminology in this paper that is considered to be more widely used in the conservation literature. If the reader goes on to examine Reimaanlok directly, "conservation features" are referred to there as "Conservation Targets" and "conservation targets" as "Conservation Goals."

\section{Acknowledgments}

Financial support was initially provided for this project by the Australian Government under the Regional Natural Heritage Programme, with additional funding from AusAID, the United Nations Development Programme (UNDP), and the Global Environment Facility (GEF). The authors acknowledge the contributions to this work of members of the Reimaan National Planning Team and the holders of local and traditional knowledge who were interviewed in the course of the project. The project received significant support and in-kind contributions from a range of organisations including the Marshall Islands Marine Resources Authority (MIMRA), the Republic of the Marshall Islands Environment Protection Authority (RMIEPA), the RMI Office of Environmental Planning and Policy Coordination (OEPPC), the College of the Marshall Islands (CMI), the Marshall Islands Conservation Society (MICS), the Marshall Islands Visitors Authority (MIVA), the Nature Conservancy (TNC), and the International Centre for Environmental Management (ICEM). The authors thank Dan Zwartz and Paul Garrett for reading drafts of the paper.

\section{References}

[1] T. P. Hughes, A. H. Baird, D. R. Bellwood et al., "Climate change, human impacts, and the resilience of coral reefs," Science, vol. 301, no. 5635, pp. 929-933, 2003.

[2] J. M. Pandolfi, R. H. Bradbury, E. Sala et al., "Global trajectories of the long-term decline of coral reef ecosystems," Science, vol. 301, no. 5635, pp. 955-958, 2003.
[3] O. Hoegh-Guldberg, P. J. Mumby, A. J. Hooten et al., "Coral reefs under rapid climate change and ocean acidification," Science, vol. 318, no. 5857, pp. 1737-1742, 2007.

[4] J. B. C. Jackson, "Ecological extinction and evolution in the brave new ocean," Proceedings of the National Academy of Sciences of the United States of America, vol. 105, no. 1, pp. 11458-11465, 2008.

[5] S. A. Sandin, J. E. Smith, E. E. DeMartini et al., "Baselines and degradation of coral reefs in the Northern Line Islands," PLoS ONE, vol. 3, no. 2, article no. e1548, 2008.

[6] J. B. C. Jackson, M. X. Kirby, W. H. Berger et al., "Historical overfishing and the recent collapse of coastal ecosystems," Science, vol. 293, no. 5530, pp. 629-637, 2001.

[7] E. L. Peterson, M. Beger, and Z. T. Richards, "Thinking outside the reef," Science, vol. 319, no. 5871, p. 1759, 2008.

[8] C. M. Crain et al., "Understanding and managing human threats to the coastal marine environment," Annals of the New York Academy of Sciences, vol. 1162, pp. 39-62, 2009.

[9] P. J. Mumby and R. S. Steneck, "Coral reef management and conservation in light of rapidly evolving ecological paradigms," Trends in Ecology and Evolution, vol. 23, no. 10, pp. 555-563, 2008.

[10] E. T. Game, E. McDonald-Madden, M. L. Puotinen, and H. P. Possingham, "Should we protect the strong or the weak? Risk, resilience, and the selection of marine protected areas," Conservation Biology, vol. 22, no. 6, pp. 1619-1629, 2008.

[11] K. H. Redford, P. Coppolillo, E. W. Sanderson et al., "Mapping the conservation landscape," Conservation Biology, vol. 17, no. 1, pp. 116-131, 2003.

[12] K. A. Wilson, M. Cabeza, and C. J. Klein, "Fundamental concepts of spatial conservation prioritization," in Spatial Conservation Prioritisation: Quantitative Methods and Computational Tools, A. Moilanen, K. A. Wilson, and H. P. Possingham, Eds., vol. 16, p. Äì27, Oxford University Press, Oxford, UK, 2009.

[13] C. R. Margules and R. L. Pressey, "Systematic conservation planning," Nature, vol. 405, no. 6783, pp. 243-253, 2000.

[14] R. E. Johannes, "The renaissance of community-based marine resource management in Oceania," Annual Review of Ecology and Systematics, vol. 33, pp. 317-340, 2002.

[15] M. Beger, "The state of coral reef ecosystems of the Marshall Islands," in The State of Coral Reef Ecosystems of the United States and Pacific Freely Associated States, J. E. Waddell and A. Clarke, Eds., pp. 330-361, NOAA, 2008.

[16] Z. T. Richards, M. Beger, S. Pinca, and C. C. Wallace, "Bikini Atoll coral biodiversity resilience five decades after nuclear testing," Marine Pollution Bulletin, vol. 56, no. 3, pp. 503-515, 2008.

[17] N. Baker and B. Chutaro, Capacity Building Needs Assessment for Biodiversity Conservation in the Marshall Islands, Republic of the Marshall Islands Office of Environmental Policy and Planning Coordination, Majuro, Marshall Islands, 2004.

[18] N. Baker and M. Haws, "The Marshall Islands," in Natural Resources Management Needs for Coastal and Littoral Marine Ecosystems of the U.S. Affiliated Pacific Islands: American Samoa, Guam, Commonwealth of the Northern Marianas Islands, Republic of the Marshall Islands, Federated States of Micronesia and the Republic of Palau, Hawaii Cooperative Studies Unit, University of Hawaii, Technical Report HCSU002, Hilo, Hawaii, USA, 2006.

[19] Micronesia Challenge, "2nd regional meeting of the micronesia challenge," in Micronesia Challenge Pohnpei, Federated States of Micronesia, 2008. 
[20] J. E. Cinner and S. Aswani, "Integrating customary management into marine conservation," Biological Conservation, vol. 140, no. 3-4, pp. 201-216, 2007.

[21] W. R. Dickinson, "Impacts of eustasy and hydro-isostasy on the evolution and landforms of Pacific atolls," Palaeogeography, Palaeoclimatology, Palaeoecology, vol. 213, no. 3-4, pp. 251269, 2004.

[22] G. A. J. Scott and G. M. Rotondo, "A model for the development of types of atolls and volcanic islands on the Pacific lithospheric plate," Atoll Research Bulletin, vol. 260272, no. 260, pp. 1-33, 1983.

[23] D. H. R. Spennemann, Essays on the Marshallese Past, Albury, 2nd edition, 1998.

[24] EPPSO, "Economics Planning Policy and Statistics Office of the Marshall Islands," 2007, http://www.spc.int/prism/ country/mh/stats/Economic/eco_index.htm.

[25] C. C. H. Petrosian-Husa, "Traditional fishing techniques on the Marshall Islands," Alele Report 2004/03, Republic of the Marshall Islands Historic Preservation Office, Majuro, Marshall Islands, 2004.

[26] A. Anjain-Maddison, "Personal communication," 2010.

[27] J. E. Randall and H. A. Randall, "Annotated checklist of the fishes of Enewetok Atoll and the Marshall Islands," in The Natural History of Enewetak Atoll, D. M. Devaney, Ed., pp. 289-324, U.S. Department of Energy, Office of Scientific and Technical Information, Oak Ridge, Tenn, USA, 1987.

[28] D. M. Devaney and J. C. Lang, "Annotated checklist of the scelectarians of Enewetok Atoll and the Marshall Islands," in The Natural History of Enewetak Atoll, D. M. Devaney, Ed., pp. 289-324, U.S. Department of Energy, Office of Scientific and Technical Information, Oak Ridge, Tenn, USA, 1987.

[29] National Biodiversity Team Republic of the Marshall Islands, The Marshall Islands-Living Atolls Amidst the Living Sea: The National Biodiversity Report of the Republic of the Marshall Islands, RMI Biodiversity Project, Majuro, Marshall Islands, 2000.

[30] J. Niedenthal, For the Good of Mankind: A History of the People of Bikini and Their Islands, Bravo Publishers, Majuro, Marshall Islands, 2nd edition, 2001.

[31] S. L. Simon, "A brief history of people and events related to atomic weapons testing in the Marshall Islands," Health Physics, vol. 73, no. 1, pp. 5-20, 1997.

[32] S. L. Simon and J. C. Graham, "Findings of the first comprehensive radiological monitoring program of the republic of the Marshall Islands," Health Physics, vol. 73, no. 1, pp. 66-85, 1997.

[33] L. R. Donaldson, A. H. Seymour, and A. E. Nevissi, "University of Washington's radioecological studies in the Marshall Islands, 1946-1977," Health Physics, vol. 73, no. 1, pp. 214222, 1997.

[34] I. Kapoor, "Towards participatory environmental management?" Journal of Environmental Management, vol. 63, no. 3, pp. 269-279, 2001.

[35] K. S. Bawa, R. Seidler, and P. H. Raven, "Reconciling conservation paradigms," Conservation Biology, vol. 18, no. 4, pp. 859-860, 2004.

[36] J. A. Drew, "Use of traditional ecological knowledge in marine conservation," Conservation Biology, vol. 19, no. 4, pp. 12861293, 2005.

[37] S. M. Evans and A. C. Birchenough, "Community-based management of the environment: lessons from the past and options for the future," Aquatic Conservation: Marine and Freshwater Ecosystems, vol. 11, no. 2, pp. 137-147, 2001.
[38] M. Beger, A. R. Harborne, T. P. Dacles, J.-L. Solandt, and G. L. Ledesma, "A framework of lessons learned from communitybased marine reserves and its effectiveness in guiding a new coastal management initiative in the Philippines," Environmental Management, vol. 34, no. 6, pp. 786-801, 2004.

[39] C. Groves et al., Designing a Geography of Hope: A practitioner, Äôs Handbook for Ecoregional Conservation Planning, The Nature Conservancy, Washington, DC, USA, 2nd edition, 2000.

[40] C. R. Groves, Drafting a Conservation Blueprint: A Practitioners' Guide to Planning for Biodiversity, Island Press, Washington, DC, USA, 2003.

[41] A. Green, S. E. Smith, G. Lipsett-Moore et al., "Designing a resilient network of marine protected areas for Kimbe Bay, Papua, New Guinea," ORYX, vol. 43, no. 4, pp. 488-498, 2009.

[42] The Nature Conservancy, A Blueprint for Conserving the Biodiversity of the Federated States of Micronesia, The Nature Conservancy Micronesia Program Office Pohnpei, 2002.

[43] N. Baker, Ed., Reimaanlok: Looking to the Future-National Conservation Area Plan for the Marshall Islands 2007-2012, Melbourne, Australia, 2008.

[44] S. Andréfouët, Millennium Coral Reef Mapping Project, Institute for Marine Remote Sensing (IMaRS), 2005.

[45] L. Fernandes, J. Day, A. Lewis et al., "Establishing representative no-take areas in the great barrier reef: largescale implementation of theory on marine protected areas," Conservation Biology, vol. 19, no. 6, pp. 1733-1744, 2005.

[46] S. Airamé, J. E. Dugan, K. D. Lafferty, H. Leslie, D. A. McArdle, and R. R. Warner, "Applying ecological criteria to marine reserve design: a case study from the California Channel Islands," Ecological Applications, vol. 13, no. 1, pp. S170-S184, 2003.

[47] T. P. Hughes et al., "The Townsville declaration on coral reef research and management," in James Cook University Media Release, Townsville, Australia, 2002.

[48] M. Beger and H. P. Possingham, "Environmental factors that influence the distribution of coral reef fishes: modeling occurrence data for broad-scale conservation and management," Marine Ecology Progress Series, vol. 361, pp. 1-13, 2008.

[49] J. Carwardine et al., "Hitting the target and missing the point: target-based conservation planning in context," Conservation Letters, vol. 2, no. 1, pp. 4-11, 2009.

[50] M. King and U. Faasili, "Community-based management of subsistence fisheries in Samoa," Fisheries Management and Ecology, vol. 6, no. 2, pp. 133-144, 1999.

[51] H. Govan et al., Locally-Managed Marine Areas: A Guide for Practitioners, The Locally-Managed Marine Area Network, 2008. 

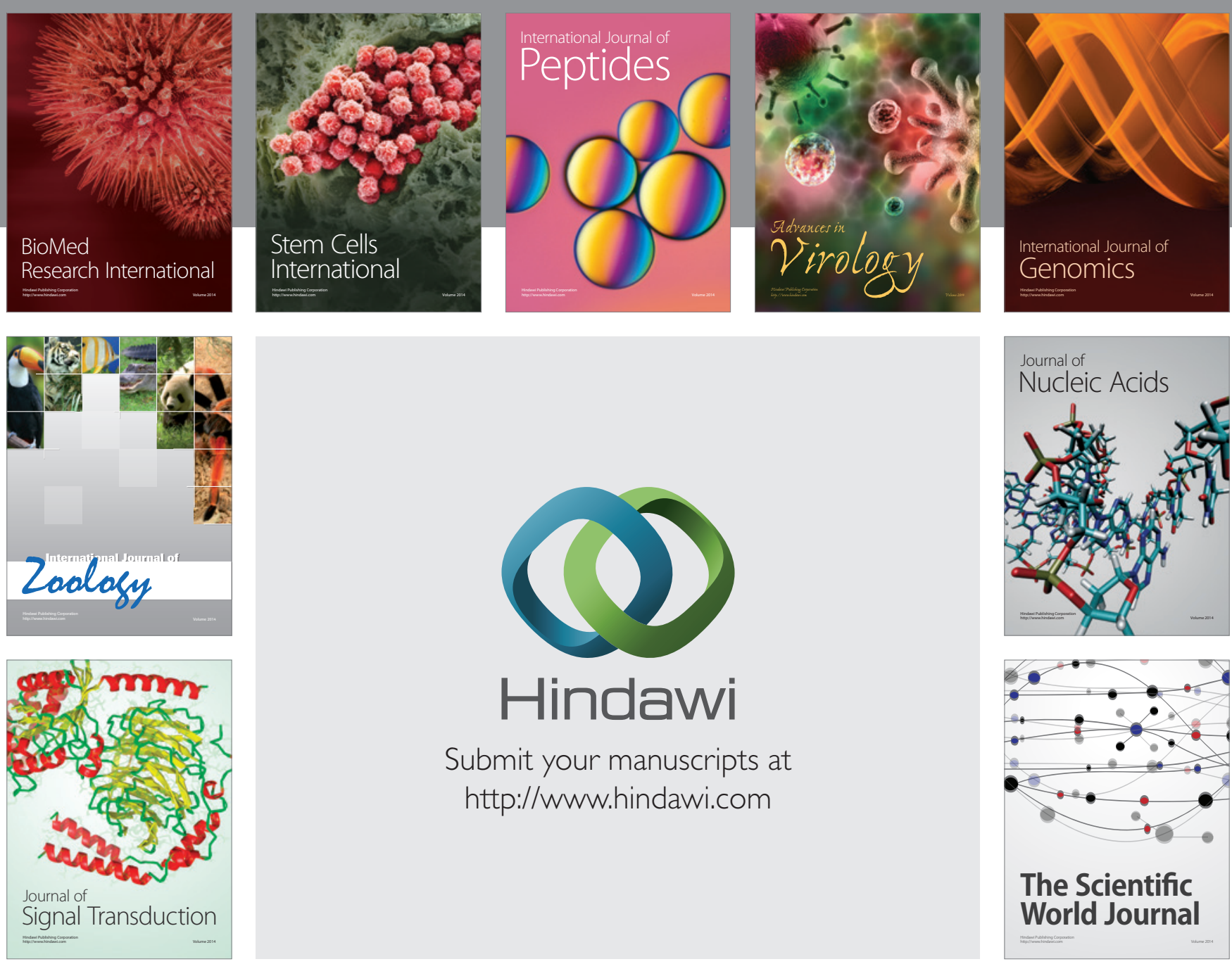

Submit your manuscripts at

http://www.hindawi.com
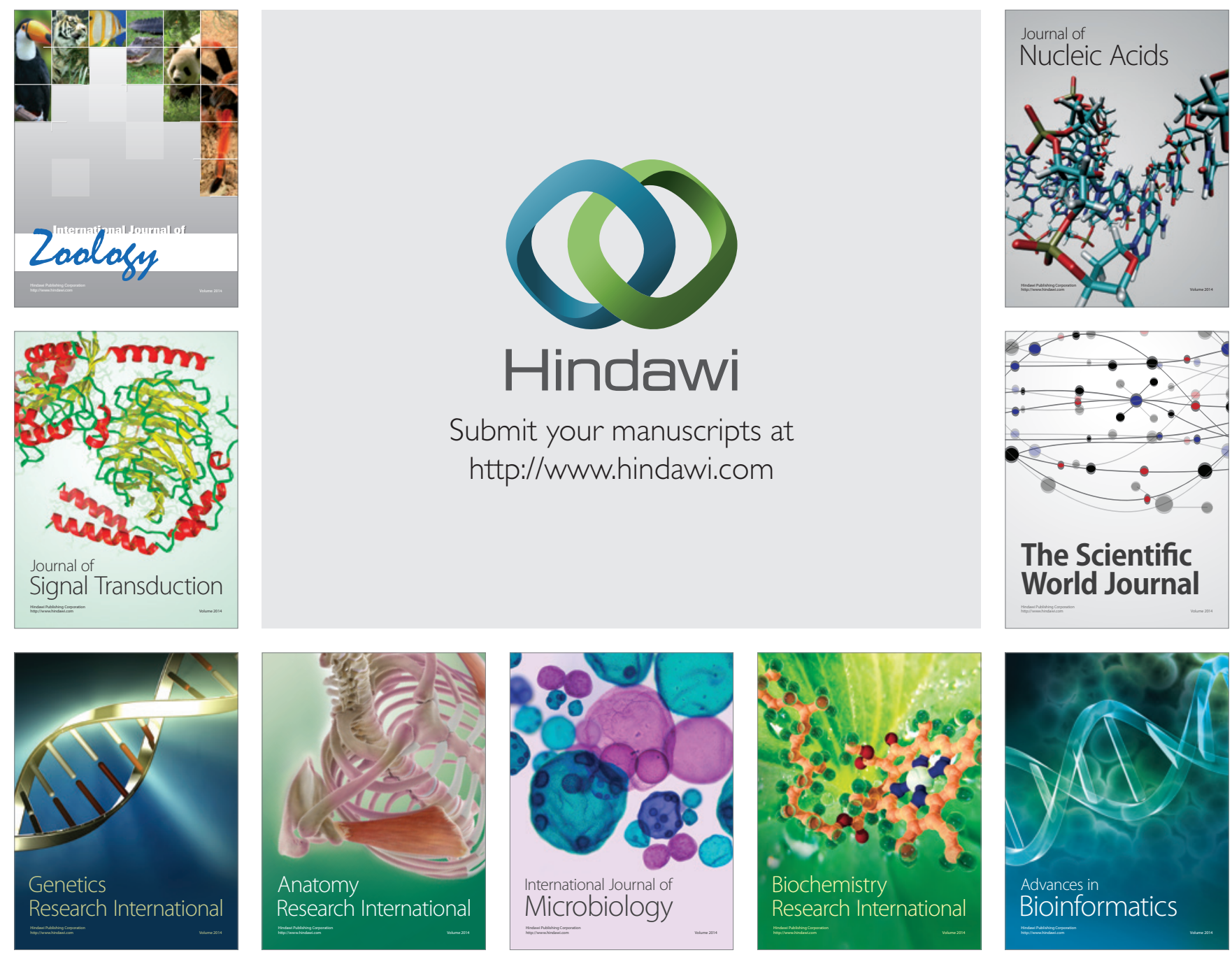

The Scientific World Journal
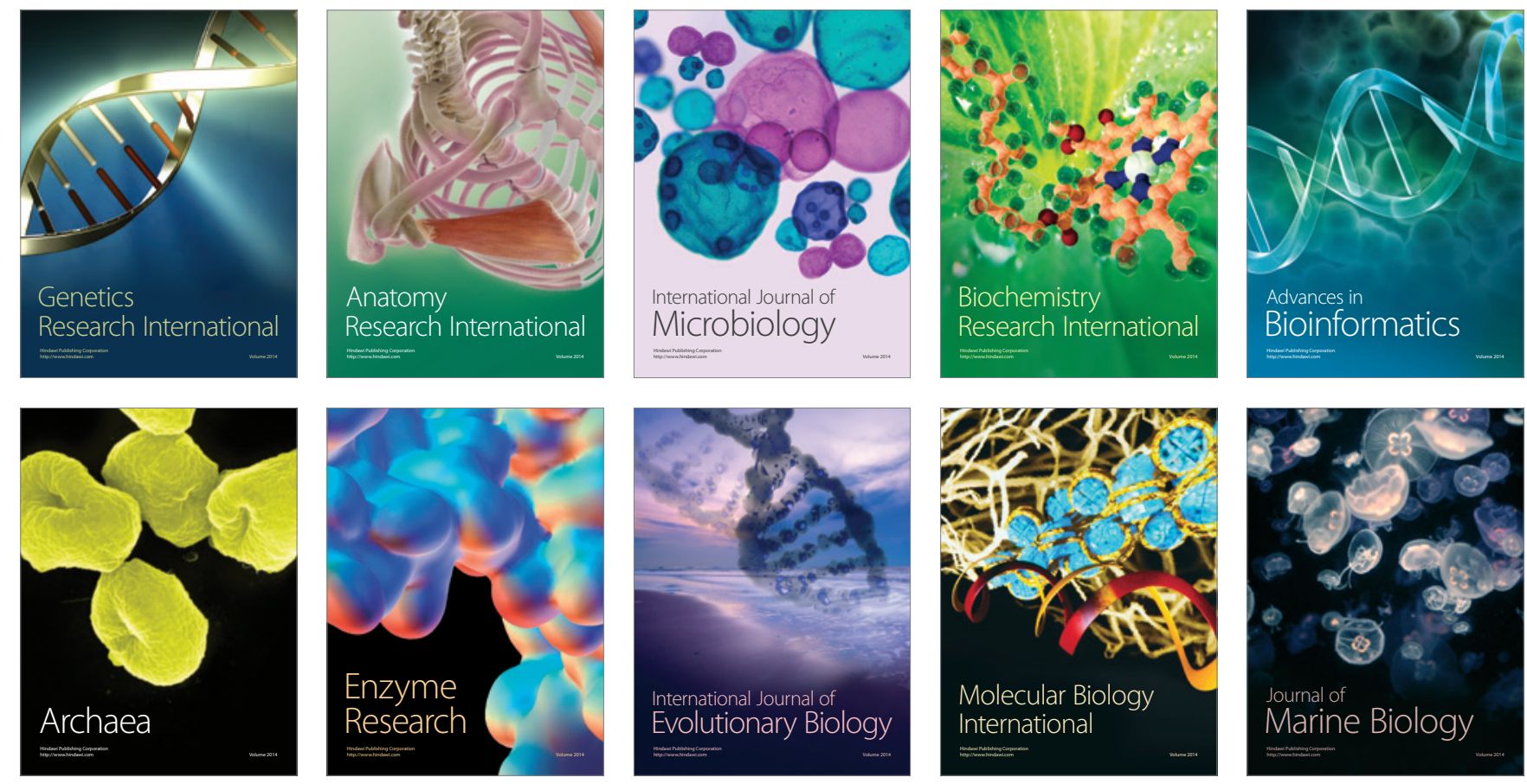